\title{
Editorial
}

\section{Prêmio de Consultores do Ano 2011}

É com muita satisfação que entregamos à comunidade o número um do vigésimo oitavo volume da Revista Psicologia Teoria e Pesquisa. Este editorial tem como objetivo principal apresentar uma nova ação implementada pela diretoria da Revista, além de compartilhar algumas notícias alvissareiras com a comunidade de leitores e autores da PTP. Todas estas ações e informações têm como propósito a melhoria continuada da qualidade da Revista, compromisso assumido por todas as diretorias da PTP.

Iniciemos, então, pelas boas notícias do início de 2012. Ao final de 2011 a Revista foi convidada, junto com várias outras revistas brasileiras pela comissão de área de Psicologia da CAPES, para apresentar pleito visando receber apoio com o objetivo de internacionalização da Revista. Após ampla consulta ao conselho editorial, a diretoria da Revista elaborou uma proposta descrevendo metas a serem alcançadas, bem como os meios necessários para o alcance de tais metas. Em meados de janeiro do presente ano fomos informados de que a Revista PTP foi uma das duas selecionadas para ingressar no programa. Esta indicação já resultou no incremento de avaliação da Revista no Qualis-CAPES 2012, no qual a Revista PTP passou a ser classificada como A1, extrato máximo do sistema de avaliação de periódicos da CAPES.

Agradeço a todos os que se empenharam na elaboração de uma proposta competitiva que resultou na indicação da PTP ao programa. Estamos certos de que este é o reconhecimento de um trabalho sério e comprometido da atual diretoria e conselho editorial, bem como de todos àqueles que nos precederam, visando o aumento continuado e sustentável da qualidade da Revista. Seguimos com nossas metas de internacionalização, por meio do pleito de indexação no ISI, que foi renovado neste ano de 2012, e, agora, aguardamos que a execução do programa da CAPES nos permita dar sustentabilidade para o alcance das metas e garantir um processo seguro de internacionalização. A Revista PTP continua com sua premissa de veicular artigos da produção científica da Psicologia Brasileira em todas as suas áreas e esperamos que a internacionalização da Revista possa auxiliar no aumento da visibilidade internacional da produção científica da Psicologia feita no Brasil.

O segundo e principal tema a ser tratado neste editorial diz respeito ao anúncio do prêmio de consultores do ano 2011 da Revista Psicologia Teoria e Pesquisa. Uma preocupação central da atual diretoria é com a profissionalização continuada do processo editorial da Revista. Um processo editorial profissionalizado, graças ao cuidado e preocupação com a qualidade e celeridade de informações e produtos por todos os envolvidos no processo (i.e. autores, editores e consultores), é essencial para o prestígio e qua- lidade de um periódico. Consideramos que o trabalho dos consultores é essencial, pois são estes atores que, de forma desprendida e sem reconhecimento pecuniário, executam um trabalho fundamental na elaboração de pareceres que, quando qualificados, permitem uma decisão editorial mais acurada e promotora do incremento sistemático da qualidade do conhecimento produzido. Pensando no papel essencial que o consultor tem neste processo é que definimos por instituir o prêmio anual de consultores da PTP, estabelecendo-se, assim, um reconhecimento ao trabalho executado. Trata-se de um reconhecimento simbólico, pois a Revista não tem recursos para um reconhecimento de natureza distinta, mas seu propósito é estimular e valorizar o trabalho de consultoria, essencial para a qualidade de qualquer periódico e, de forma ampla, da própria área.

A Revista possui editorias associadas, organizadas pelas grandes áreas temáticas de produção da Psicologia. Durante o ano de 2011 nossos Editores Associados avaliaram o trabalho de nossos consultores em duas dimensões principais: (a) qualidade dos pareceres recebidos, conforme os critérios de avaliação de manuscritos adotados por PTP, considerando, principalmente, a eficiência do parecer em possibilitar uma decisão editorial qualificada; e (b) celeridade e cumprimento de prazo para execução das tarefas editoriais. Com base nestas avaliações nossos Editores Associados selecionaram quatro consultores, que homenageamos neste editorial e que receberão, muito em breve, certificado para comprovação da homenagem. Sendo assim, vamos aos homenageados:

- Aderson Luiz da Costa Júnior (UnB)

- Fabio Scorsolini-Comin (UFTM)

- Liana Fortunato Costa (UnB)

- Marcus Bentes de Carvalho Neto (UFPA)

Agradecemos a todos os Consultores da Revista que colaboraram na emissão de pareceres ao longo do ano de 2011 e convidamos a todos para a busca continuada da qualidade na emissão de pareceres. Pareceres que respeitam prazos e são peças argumentativas que efetivamente logram subsidiar o editor em uma decisão editorial são fundamentais para um processo editorial profissionalizado. Esperamos que o prêmio se institua como um estímulo à qualificação de um trabalho, muitas vezes, deixado em segundo ou terceiro plano por muitos membros de nossa comunidade, mas que se constitui como um dos principais pilares do processo autocorretivo da ciência.

Ronaldo Pilati Editor-Chefe 